\title{
Physicochemical and Biochemical Characteristics of the Underutilized Elateriospermum Tapos
}

\author{
Nurdiyana Husina, Nuraimi Azlan Hadi Tana, Ida Idayu Muhamada*, Norazlina Mohd Nawia \\ ${ }^{a}$ Bioprocess Engineering Department, Faculty of Chemical Engineering \& Cardiovascular Engineering Centre, IJN-UTM, Universiti Teknologi \\ Malaysia Johor Bahru, Johor, Malaysia \\ *Corresponding author: idayu@cheme.utm.my
}

\section{Article history}

Received :29 July 2013

Received in revised form:

23 September 2013

Accepted :29 September 2013

\section{Graphical abstract}

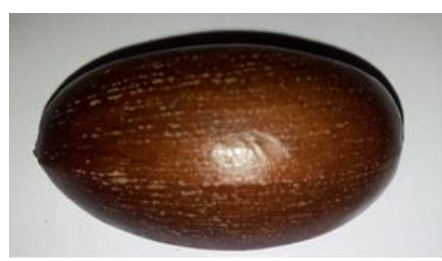

\section{Abstract}

The nutritional and antinutritional value of fresh and fermented perah seed were studied. The colour of fermented perah seed changed from beige into dark brown and strong pleasant smell was developed. From proximate analysis, fermented perah seed contained lower moisture, protein, fiber and ash compare to fresh perah seed. Interestingly, the fat content increased after fermentation process for about $9 \%$. On the other hand, about consistent protein content was retained after fermentation process resulted in less than $4 \%$ from fresh perah seed. In comparison with other types of seeds, perah seed shows relatively high content in protein (59\%) and fiber (77\%). Mineral analysis showed a reduced amount of heavy metal in perah after fermentation compare to fresh seed. Meanwhile, antinutritional analysis found very insignificant untraceable presence of cyanide in both types of the seeds. Therefore, it can be concluded that traditional practice of fermenting perah seed before consumption is indeed practical to retain optimum nutrition content, prolonged shelf life with seven times lower moisture content also reduction in cyanide traces and heavy metals compared to the fresh perah seed.

Keywords: Nutritional factor; antinutritional factor; fermented perah seed; fresh perah seed; Elateriospermum tapos

\begin{abstract}
Abstrak
Kandungan nutrisi dan anti-nutrisi di dalam buah perah yang segar dan buah yang diperam telah dikaji. Isi buah perah yang telah diperam berubah warna dari kuning air menjadi perang gelap dan mempunyai bau enak yang kuat. Analisa proksimat mendapati buah perah peraman mempunyai kandungan air, protein, abu dan serat yang lebih rendah berbanding buah perah yang segar. Manakala hasil analisis yang menarik ialah kandungan lemak isi buah perah peraman meningkat sebanyak $9 \%$ dari asal. Walau bagaimanapun, kandungan protein dalam buah perah segar dan selepas peraman tidak banyak berbeza iaitu kurang daripada $4 \%$ yang menunjukkan kandungan protein yang konsisten dikekalkan selepas proses pemeraman. Berdasarkan perbandingan dengan biji-bijian yang lain, buah perah menunjukkan kandungan protein $(59 \%)$ dan serat $(77 \%)$ yang tinggi secara relatif. Analisis mineral pula mendapati kandungan asal logam berat menurun selepas proses pemeraman. Berdasarkan analisis antinutrisi pula mendapati kandungan sianida terlalu rendah dan tidak dapat dikesan di dalam kedua-dua buah perah segar dan peraman. Oleh itu dapat dirumuskan bahawa amalan tradisi pemeraman buah perah sebelum dimakan amat praktikal, dapat mengekalkan kandungan nutrisi secara optimum, jangka hayat yang lebih lama kerana penurunan tujuh kali ganda kandungan lembapan dan pengurangan unsur sianida serta kandungan logam berat berbanding kandungan buah yang segar.
\end{abstract}

Kata kunci: Nutrisi; antinutrisi; buah perah peraman; buah perah segar; Elateriospermum tapos

(C) 2013 Penerbit UTM Press. All rights reserved.

\subsection{INTRODUCTION}

Elateriospermum tapos or locally known as buah perah or perah tree is a species of plant of Euphorbiaceace family and can be classified into subfamily of Crotonoideae and Elateriospermeae tribe. It is wildly found in Southeast Asian tropical rainforest which includes peninsular Malaysia, peninsular Thailand, Brunei, Sumatra, Java and Borneo ${ }^{1,2}$. In Malaysia, this species found to be dominated in Jengka Forest Reserve, Peninsular Malaysia ${ }^{1}$. E. tapos is more popularly known as perah or pogoh nut (Malaysia), kedui or tapos (Indonesia) and look-kra or lookpra (Thailand) ${ }^{2}$. This fine tree however may be considered as wild fruit tree, usually easily spotted as a large tree $(80-140 \mathrm{ft})$ with eye catching bright red colored young leaves in flushes. The perah fruits are about 5.5-6 cm long, oblong, buff color and more or less suffused pink on the exposed side, hanging singly 
on stalk $3-15 \mathrm{~cm}$ long. The perah seeds are about $4 \mathrm{~cm}$ long in shining brown with a faint ridge on each side ${ }^{3}$.

This tree has a value where almost every part of it can be utilized. Perah tree was well known as medium hardwood timber for railway sleepers, parquet flooring, fence posts, tool handles and suitable for both heavy and medium construction. In Sarawak, this tree is utilized for making the poles used to pound rice. Moreover, it is mainly used as firewood or for small items such as nicely polished handles of rubber tapping knives. It needs to be treated with preservatives for use as construction timber because the heartwood rots easily or is attacked by termites, but only the sapwood is durable. The latex is also used to polish blowpipes to glossy dark sheen by locals in Peninsular Malaysia. In addition, the leaves too are made edible by the Sarawakian ${ }^{3}$.

Perah seed is type of seed that easily planted and found abundance especially in the east coast of Malaysia and also southern of Thailand. The locals consumed perah in fresh and fermented forms but cautiously because consuming in large amount will cause dizziness and nausea. However, perah is well known for its medicinal and nutritional value apart from its antinutritional value. Hence it will useful to determine the nutritional and antinutritional contents of the fresh perah seeds, also the content of fermented perah seed with reference to Popoola et al. ${ }^{4}$ who reported that fermentation process could improve nutritive value, increase digestibility, destroy some natural toxins which may occur and improve the seeds' flavor. Information about the content of the seeds before and after fermentation is needed in order to know the most suitable way in consuming the seeds. Source of protein or other potential substances found from perah seed can be a new source of essential nutrition ${ }^{5}$. Moreover, perah could also be an alternate and cheap source of proteins against the high cost of animal proteins.

\subsection{EXPERIMENTAL}

\subsection{Preparation of the Seed Powder}

Fresh perah seeds were bought from a farm at Hulu Trengganu. Fermented perah were those peeled seeds kept in salted water for about two weeks obtained from local market. The seeds were selected accordingly to their condition where damaged seeds were discarded, seeds in good condition were peeled, cleaned and dried at temperature of $100-105^{\circ} \mathrm{C}$ for $30 \mathrm{~min}$. Fresh and fermented perah seeds were analysed to determine the physicochemical properties, proximate analysis, mineral analysis and antinutritional contents. Samples of seeds were ground using a dry blender. The fine seeds powders were stored in a screw cap bottles at room temperature for further analysis.

\subsection{Physicochemical Properties Analysis}

Physicochemical properties were done based on visual observation. The seeds were analyzed for its texture, shape, colour and smell based on its physical appearances before and after fermentation process.

\subsection{Proximate Analysis}

The moisture content was analyzed by using moisture content analyzer ${ }^{6}$. The content of crude protein was determined by using burette reagent method while the crude fat and ash content was estimated using method from Chopra and Kanwar ${ }^{7}$. Crude fibre content was obtained following the method from Nielsen ${ }^{8}$.

\subsection{Mineral Analysis}

The powdered seeds were analyzed by ICP-MS analyzer, ELAN 6100 . The cross flow nebulizer at $1.2 \mathrm{ml} / \mathrm{min}$ with $0.75 \mathrm{~mm}$ i.d peristaltic pump with pump speed $24 \mathrm{rpm}$.

\subsection{Antinutritional Analysis}

Antinutritional analysis that carried out was cyanide test following Chopra and Kanwar ${ }^{7}$. The presence of cyanide will be detected by the colour change of the gas collected from the $\mathrm{HCl}$ reaction with the powdered seeds sample.

\subsection{RESULTS AND DISCUSSION}

\subsection{Physicochemical Properties of Perah Seed}

Physicochemical properties analysis of perah seed was carried out to identify the characteristics before and after the fermentation process. The observed physical characteristics that recorded in this analysis were texture, shape, colour and smell of the seeds. Table 1 shows the physical characteristics of perah seeds before and after the fermentation process.

The fresh perah seed was found to have a less cohesive texture than the fermented perah seed. This might relate to the amount of moisture content in both types of seeds. Fermented perah seed has lower moisture content, so its texture more firm than the fresh seed. Both seeds were brown in colour but the fermented seed was darker than the fresh colour. The physical appearances of fresh unpeeled, peeled and fermented perah seed are shown in Figure 1,2 and 3 respectively. The fermentation also obviously generated stronger pleasant smell of seed compare to the fresh one.

Table 1 Characteristics of fresh and fermented perah seeds

\begin{tabular}{lll}
\hline & \multicolumn{2}{c}{ Type of perah seeds } \\
\cline { 2 - 3 } Properties & Fresh & Fermented \\
\cline { 2 - 3 } Texture & Less cohesive & Cohesive/Smooth \\
Shape & Ellipse & More shrinkage/dry \\
Colour & Beige & Dark brown \\
Smell & Less smell & Strong pleasant smell \\
\hline
\end{tabular}

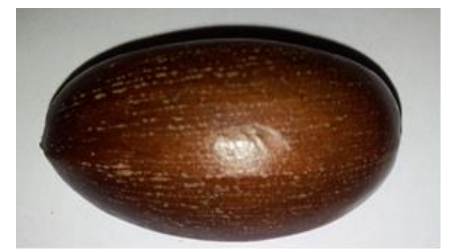

Figure 1 Fresh perah seed with hard skin (unpeeled)

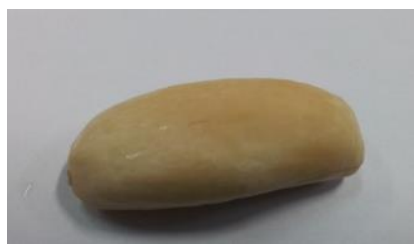

Figure 2 Fresh perah seed (peeled) 


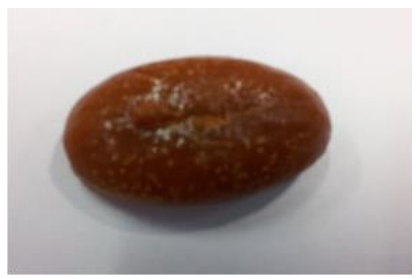

Figure 3 Fermented perah seed (peeled)

\subsection{Proximate Analysis of Fresh and Fermented Perah Seed}

\subsubsection{Composition of Perah Seed}

Table 2 shows the proximate composition of perah seed before and after fermentation. The results show that the contents of moisture and crude fiber were significantly decreased after the fermentation process. However, the crude fat content slightly increased from $27.59 \pm 1.59 \mathrm{~g}$ to $30.09 \pm 0.92$ grams. A similar pattern was reported by Popoola et al. ${ }^{4}$ when the proximate analysis were carried out on fermented and non-fermented soy bean where only fat contents increased while other contents decreased. The moisture content of the seed remarkably reduced to $5.25 \pm 0.15 \%$ from $38.65 \pm 0.15 \%$ after the fermentation process. This could be the main benefit of the fermentation process where the shelf life of the seed is prolonged and enhanced during storage in fermented form ${ }^{9}$.

Table 2 Chemical composition of perah (E.tapos) whole seed.

\begin{tabular}{llll}
\hline $\begin{array}{l}\text { Proximate } \\
\text { Analysis }\end{array}$ & Fresh Perah Seed & $\begin{array}{l}\text { Fermented } \\
\text { Seed }\end{array}$ & Perah \\
\hline Moisture $(\%)$ & $38.65 \pm 0.15$ & $5.25 \pm 0.15$ & \\
Ash $(\%)$ & $4.80 \pm 0.73$ & $3.22 \pm 0.08$ & \\
Crude Protein $(\mathrm{g})$ & $59.32 \pm 3.72$ & $56.80 \pm 2.11$ & \\
Crude Fat $(\mathrm{g})$ & $27.59 \pm 1.59$ & $30.09 \pm 0.92$ & \\
Crude Fiber $(\mathrm{g})$ & $77.88 \pm 1.8$ & $10.01 \pm 1.01$ & \\
\hline
\end{tabular}

Mean \pm sd of two replicate analyses

Results expressed as $\mathrm{g} / 100 \mathrm{~g}$

The ash content of the fermented seeds also showed about $33 \%$ reduction from the fresh content. In contrast, Enujiugha reported on his work that the amount of ash in seeds increased after fermentation process due to the metabolic activities produced by the fermenting microorganism ${ }^{10}$.

For the crude protein content, fresh perah seed showed a high amount of protein content of $59.32 \pm 3.72 \mathrm{~g}$ which slightly reduced into $56.80 \pm 2.11 \mathrm{~g}$ after fermentation. The crude protein content was not much affected by the fermentation process. As reported by Popoola et al. ${ }^{4}$ in their work, the amount of protein also decreased (4.18 g) after fermentation process. However, this finding also contradicting with Enujiugha (2003) ${ }^{10}$ who reported the amount of protein content increased after the fermentation process. This extra protein perhaps due to the microorganism such as Bacillus that he used to ferment the seeds also produced extra cellular enzyme which contain amino acid.

Meanwhile, crude fiber content in the raw seed noticeably decreased after the fermentation process from $79.68 \mathrm{~g}$ to $9.00 \mathrm{~g}$. Reported in Enujiugha (2003) ${ }^{10}$, crude fiber content decreased probably due to the activity of the microorganisms that hydrolysed celluloses and hemicelluloses as complex polysaccharides in the seeds. From the results, it shows that consumption of both types of perah seeds either in fresh or fermented forms contribute specifically in the nutritional aspects. In addition, fermented form of perah seed could preserved most nutrients and prolong the shelf life during storage.

\subsubsection{Comparison Between Perah Seed and Other Seeds from Literature}

Table 3 shows a comparison on proximate analysis between perah seed and soybean contents. The result shows that perah seed has less moisture content from the fermentation process compared to soybean. Moisture content is an important parameter which will reflect the shelf life of the seeds. The lower the moisture content the better the shelf life of the seeds 9 . After fermentation, the moisture contents of soybean was still high which was $40.07 \%$ compare to perah seed where only about $5.25 \%$ of moisture left in the seed.

For the ash analysis, the result was quite similar between perah seed and soybean. The trend was also similar where the ash content decreased after fermentation process. The result of crude protein analysis shows that perah seed contained higher protein compare to soybean either in non-fermented or fermented seeds. Perah seed showed the degradation of $4 \%$ of protein after the fermentation process, while soybeans showed slightly higher for about $8 \%$ degradation. Popoola et al. ${ }^{4}$ suggested that the protein content might lost in the preparation of fermentation which happened during the soaking and blanching process. Fermentation process also caused two times more reduction in fiber content of perah than soybean. In contrast to those effects, fat content after fermentation slightly increased in perah but remarkably in soybean.

Table 3 Comparison of proximate composition in non-fermented and fermented perah seed with soy bean

\begin{tabular}{|c|c|c|c|c|}
\hline \multirow{3}{*}{$\begin{array}{l}\text { Proximate } \\
\text { Analysis }\end{array}$} & \multicolumn{4}{|c|}{ Type of seed } \\
\hline & \multicolumn{2}{|c|}{ Perah Seed } & \multicolumn{2}{|c|}{ Soy Bean } \\
\hline & Fresh & Fermented & Fresh & Fermented \\
\hline $\begin{array}{l}\text { Moisture } \\
(\%)\end{array}$ & $38.65 \pm 0.15$ & $5.25 \pm 0.15$ & 53.73 & 40.07 \\
\hline Ash (\%) & $4.80 \pm 0.73$ & $3.22 \pm 0.08$ & 5.19 & 3.36 \\
\hline $\begin{array}{l}\text { Crude } \\
\text { Protein (g) }\end{array}$ & $59.32 \pm 3.72$ & $56.80 \pm 2.11$ & 50.09 & 45.91 \\
\hline $\begin{array}{l}\text { Crude Fat } \\
(\mathrm{g})\end{array}$ & $27.59 \pm 1.59$ & $30.09 \pm 0.92$ & 20.06 & 33.44 \\
\hline $\begin{array}{l}\text { Crude Fiber } \\
\text { (g) }\end{array}$ & $77.88 \pm 1.8$ & $10.01 \pm 1.01$ & 6.40 & 3.60 \\
\hline
\end{tabular}

The comparison of proximate analysis of fresh perah seed with other non-fermented seeds such as Canavalia gladiata ${ }^{11}$, Xylia xylocarpa ${ }^{12}$, and Canavalia ensiformis ${ }^{13}$ were listed in Table 4. From the data tabulated in the table, perah seeds have the highest moisture contents among the rest. Except for perah seed, the other three types of seeds are from the same country of origin which is India, perhaps this is the cause of their moisture contents to be quite similar (5.16\%-11.2\%). While for the ash analysis, the value was not much different between all the seeds.

The noticeable differences between those seeds were the amount of crude protein and crude fiber, in which perah seed showed the highest amount $(59.32 \pm 3.72 \mathrm{~g})$ of protein, $(77.88 \pm 1.8 \mathrm{~g})$ crude fiber and crude fat $(27.59 \pm 1.59)$ among the other seeds. The result shows that perah seed has a lot more nutritional values compare to the seeds from India that have been studied by the researchers. 
Table 4 Comparison of proximate composition in non-fermented perah seed with some other wild seeds

\begin{tabular}{|c|c|c|c|c|}
\hline \multirow[b]{2}{*}{$\begin{array}{l}\text { Proximate } \\
\text { analysis }\end{array}$} & \multicolumn{4}{|c|}{ Type of seeds } \\
\hline & Perah seed & $\begin{array}{l}\text { Xylia } \\
\text { xylocarpa }\end{array}$ & $\begin{array}{l}\text { Canavalia } \\
\text { gladiata }\end{array}$ & $\begin{array}{l}\text { Canavalia } \\
\text { ensiformis }\end{array}$ \\
\hline $\begin{array}{l}\text { Moisture } \\
(\%)\end{array}$ & $38.65 \pm 0.15$ & $5.16 \pm 0.16$ & $11.2 \pm 0.04$ & $8.5 \pm 0.3$ \\
\hline Ash (\%) & $4.80 \pm 0.73$ & $5.11 \pm 0.87$ & $3.9 \pm 0.01$ & $3.9 \pm 0.1$ \\
\hline $\begin{array}{l}\text { Crude } \\
\text { Protein }(\mathrm{g})\end{array}$ & $59.32 \pm 3.72$ & $\begin{array}{l}29.53 \pm 0.8 \\
6\end{array}$ & $26.8 \pm 0.24$ & $35.0 \pm 0.3$ \\
\hline $\begin{array}{l}\text { Crude Fat } \\
(\mathrm{g})\end{array}$ & $27.59 \pm 1.59$ & $\begin{array}{l}14.78 \pm 0.8 \\
6\end{array}$ & $2.8 \pm 0.01$ & $4.3 \pm 0.5$ \\
\hline $\begin{array}{l}\text { Crude Fiber } \\
(\mathrm{g})\end{array}$ & $77.88 \pm 1.8$ & $8.02 \pm 1.13$ & $33.1 \pm 0.70$ & $7.7 \pm 0.3$ \\
\hline
\end{tabular}

\subsection{Mineral Analysis in Fresh and Fermented Perah Seed}

From the mineral analysis result in Table 5, it indicates an increasing concentration of potassium, iron, magnesium, and nickel. From these four types of minerals, potassium gave the higher increment $(37 \%)$ after the fermentation process. Iron, magnesium and nickel only showed a small amount of increment.

Table 5 Content of certain minerals in perah seed, (ppm)

\begin{tabular}{lll}
\hline $\begin{array}{l}\text { Composition } \\
\text { (ppm) }\end{array}$ & $\begin{array}{l}\text { Fresh Perah } \\
\text { Seed }\end{array}$ & $\begin{array}{l}\text { Fermented Perah } \\
\text { Seed }\end{array}$ \\
\hline Lead, Pb & 0.04 & 0.01 \\
Mercury, Hg & 0.0001 & 0.0001 \\
Copper, Cu & 0.72 & 0.13 \\
Zinc, Zn & 9.35 & 5.94 \\
Arsenic, As & 0.05 & 0.04 \\
Iron, Fe & 9.77 & 9.80 \\
Magnesium, Mg & 1.82 & 1.93 \\
Nickel, Ni & 0.14 & 0.15 \\
Cadmium, Cd & 0.004 & 0.002 \\
Chromium, Cr & 0.08 & 0.08 \\
Cobalt, Co & 0.002 & 0.002 \\
Calcium, Ca & 35.07 & 34.62 \\
Sodium, Na & 43.66 & 22.18 \\
Phosphorus, P & ND $(<0.001)$ & $\mathrm{ND}(<0.003)$ \\
Selenium, Se & -0.02 & 0.01 \\
Aluminum, AI & 0.34 & 0.30 \\
Silver, Ag & 0.0004 & 0.0004 \\
Barium, Ba & 0.04 & 0.03 \\
Potassium, K & 19.08 & 26.19 \\
\hline (1.pon
\end{tabular}

$(1 \mathrm{ppm}=1 \mathrm{ug} / \mathrm{g})$

In the fresh perah seed, the concentration of potassium $(19.08 \mathrm{ug} / \mathrm{g})$, calcium $(35.07 \mathrm{ug} / \mathrm{g})$ and sodium $(43.66 \mathrm{ug} / \mathrm{g})$ were higher than other minerals. The same trend was observed in the fermented perah seed, where these three types of mineral showed the most remarkable amount among other minerals.

Several heavy metals detected in fresh and fermented perah seed which were lead, copper, arsenic, iron, nickel, cadmium, mercury, cobalt, and silver. According to Commission Regulation (EC) No 1881/2006, the permitted amount of these heavy metals for lead is $0.2 \mathrm{ppm}$, arsenic ( $1 \mathrm{ppm})$, cadmium $(0.2$ $\mathrm{ppm})$, mercury (1ppm) ${ }^{14}$. It is worth to be highlighted that the amount of heavy metals detected in perah seed were low in comparison to allowed amount of safety limit by FDA and other types of wild seed such as Canavalia gladiata ${ }^{11}$, Xylia xylocarpa ${ }^{12}$, and Canavalia ensiformis ${ }^{13}$.

From the measurement of mineral analysis, perah seed is more suitable to be consumed in the fermented form since most of the heavy metals were reduced after fermentation process. Furthermore, the presence of other minerals that is good for health was reserved such as potassium, calcium and sodium. Generally the mineral content of such seeds is depending on the genetic origin, geographical source, and also the level of soil fertility ${ }^{13}$.

\subsection{Antinutritional Analysis in Perah Seed}

\subsubsection{Cyanide Test}

The cyanide test was conducted in order to detect the presence of antinutritional content. The test is crucial to conduct due to cyanide content can cause poisoned and death. According to WHO (2004), the cyanide oral lethal dose is $1.4 \mathrm{mg} / \mathrm{kg}$ body weight ${ }^{15}$. Previously perah seed was reported to have cyanide in the fresh-fermented form ${ }^{2,5}$. The tests also have been done for fresh and fermented perah seed in order to determine if the cyanide still present after the fermentation process. The presence of cyanide was detected by collecting gas from the reaction between the powdered seed and hydrochloric acid. If cyanide is detected, the addition of ferric chloride solution and ferrous sulphate solution will show a change of gas colour that has been collected in the test tube.

From the experiment, the results did not show any significant change in colour between the fresh and fermented perah seed. The cyanide contents in both forms of the seeds are too little to be traceable. This might be also due to the type of perah seed tested is the type that does not contain any or significant amount of cyanide.

\subsection{CONCLUSION}

Based on the results, there are several conclusions that can be made in determining which type of seed is better for human consumption. The results showed that perah seed has good nutritional values that suitable to be a new source of high protein either in the form of fresh or fermented seeds. From both type of seeds, the fermented perah seed has better potential of nutrient values compare to the fresh seed. This is due to the longer shelf life, preservation of protein, decrease of heavy metal compositions and higher amount of potassium in the fermented seed. Meanwhile, the antinutritional factor which is cyanide content showed no significant traceable amount in both types of perah seeds.

\section{Acknowledgement}

The authors would like to acknowledge the UTM Research University Grant vot Q.J130000.2525.01H31, Ministry of Higher Education (MOHE) and Research Management Centre UTM for financial support of this project

\section{References}

[1] Osada, N., Takeda, H., Kawaguchi, H., Furukawa, A., Awang, M. 2003. Estimation of Crown Characters and Leaf Biomass from Leaf Litter in a Malaysian Canopy Species, Elateriospermum tapos (Euphorbiaceace). Forest Ecol. Manage. 177: 379-386. 
[2] Yong, Y. O., and Salimon, J. 2006. Characteristics of Elateriopermum Tapos Seed Oil as a New Source of Oilseed. Journal of Industrial Crops and Products. 24: 146-151.

[3] Corner, E. J. H. 1989. Wayside Trees of Malaya. Third edition. United Selangor Press, Kuala Lumpur.

[4] Popoola, T. O. S., and Akueshi, C. O. 1986. Nutritional evaluation of Daddawa, a Local Spice Made from Soybean (Glycine max.). MIRCEN Journal. 2: 405-409.

[5] Nuraimi, A. H. T., Bazlulmobin, S., Ida, I. M., Liza, M. S., and Nor Diana, H. 2013. Perah Oil: A Potential Substitute for Omega-3 Oils and Its Chemicals Properties. Internat. Journal of Biotechnology and Wellness Industry. 2: 22-28.

[6] Ezeagu, I. E., Petzke, J. K., Metges, C. C., Akinsoyinu, A. O., Ologhobo, A. D. 2002. Seed Protein Contents and Nitrogen-to-Protein Conversion Factors for Some Uncultivated Tropical Plant Seeds. Journal of Food Chemistry. 78: 105-109.

[7] Chopra, S. L., and Kanwar, J. S. 1976. Analytical Agricultural Chemistry. Third edition. 12: 332-341.

[8] Nielsen, S. S. 2003. Food Analysis. Kluwer Academic/Plenum Publishers.
[9] Achi, O. K. 2005. Traditional Fermented Protein Condiments in Nigeria. African Journal of Biotechnology. 4 (13): 1612-1621.

[10] Enujiugha, V. N. 2003. Nutrient Changes During the Fermentation of African Oil Bean (Pentaclethra macrophylla Benth) Seeds. Pakistan Journal of Nutrition. 2(5): 320-323.

[11] Eknayake, S., Jansz, E. R., and Nair, B. M. 1999. Proximate Composition, Mineral and Amino Acid Content of Canavalia Gladiata Seeds. Journal of Food Chemistry. 66: 115-119.

[12] Siddhuraju, P., Vijayakumari, K., and Janardhanan, K. 1994. Nutrient and Chemical Evaluation of Raw Seeds of Xylia Xylocarpa: An Underutilized Food Source. Journal of Food Chemistry. 53: 299-304.

[13] Vadivel, V., and Janardhanan, K. 2001. Diversity in Nutritional Composition of Wild Jack Bean (Canavalia ensiformis L. DC) Seeds Collected from South India. Journal of Food Chemistry. 74: 507-511.

[14] European Commission. Commission Regulation (EC) No 1881/2006 of 19 December 2006. Official Journal of the European Union.

[15] World Health Organization 2004. Hydrogen Cyanide and Cyanides: Human Health Aspects. Concise International Chemical Assessment Document 61. 